\title{
The Situation of Community Museums in the North of Thailand
}

\author{
Nitaya Kanokmongkol
}

\begin{abstract}
The community museums in the North of Thailand have different patterns: Ethnicity museums and local historical museums. Most ethnicity museums are located in the community of those ethnic people, and present ethnic identity, history, and folklore. Local historical museums are located in historical areas related to the folk life of the communities, and present the history of the areas and the communities. The author considers community museums in Thailand just one type of local museum managed by people, temples, and private units. The situations of the local museums might not be as stable as those of the national museums because the idea of each community unit is different in its understanding of the museum's social function. And nowadays, most local museums are just used as tourist places for the community economy.
\end{abstract}

\section{Introduction}

Museum establishment is not an original idea of Thailand but a Western influence when the Royal Court had a relationship with European countries in the Western colonial period of Asia. The first Thai museum started in 1857 when King Rama IV established a private collection gallery in the Royal Palace. He collected masterpieces, fragments of rare plants and animals, and scarce minerals from different regions. In the reign of King Rama V, the museum was used to present the country as a civilized land by changing it to the National Museum Bangkok open to the public and European guests. In the next reign, archaeological sites and ancient objects were protected as historical evidence, so museums had the mission of preserving, exhibiting, and teaching the public about archaeological evidence. In this time, regional national museums were established to protect artifacts in the regions (Jiraphong 1991). It was an important period for transmitting the museum idea from the Royal Court to the regional people, and introducing local museums later established by regional units and regional communities. Nowadays, the concept of the

\footnotetext{
N. Kanokmongkol $(\bowtie)$

Chiang Mai National Museum, 451 Super Highway rd., Chang Peok,

Chiang Mai 50300, Thailand

e-mail:kanitayaka@gmail.com
} 
local museum in Thailand is the "regional museum" of which there are several kinds according to the type of collection, story presentation, and organization, such as temple museums, company museums, learning museums in schools, folk museums, and community museums.

\section{Community Museum: A Subtype of the Local Museum}

Local museums in Thailand were born of the situation in each place and period. Most local museum owners are villagers who just want to build a collection gallery but without purpose or considering the type of their museum as a museological idea. Therefore, if we learn about and understand local museums in Thailand, we can know the basic situation of local Thai people. So the type of museum in Thailand should be recognized based on the understanding of the museum owner as one of three types: national museum, company or private museum (Fig. 1), or local museum.

For the types of local museum (Figs. 2 and 3), we can recognize subtypes from their collection, objective, and function. For example, a community museum is a local museum whose purpose is the following:

1. There is interaction with the community around the museum;

2. The community is the museum owner (Sirindhon Anthropology Center 2008).

3. The community uses the museum as a medium to promote their human rights or identity of ethnicity culture.

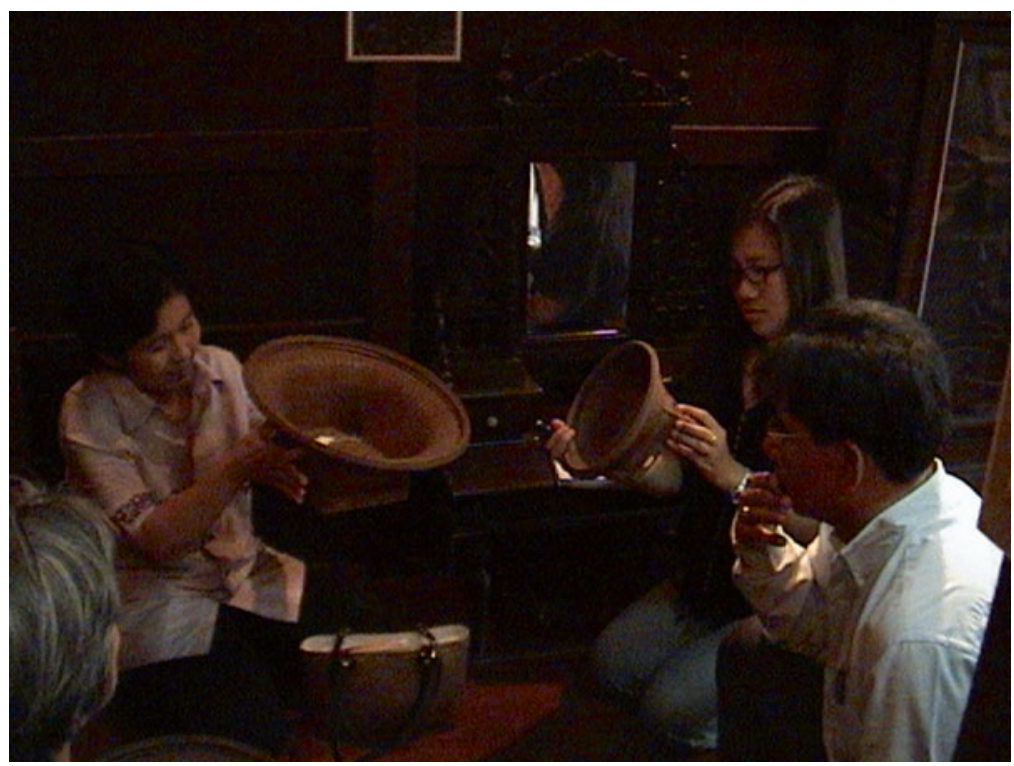

Fig. 1 Ban Kamaoon Museum, Chiang Mai: a private museum 


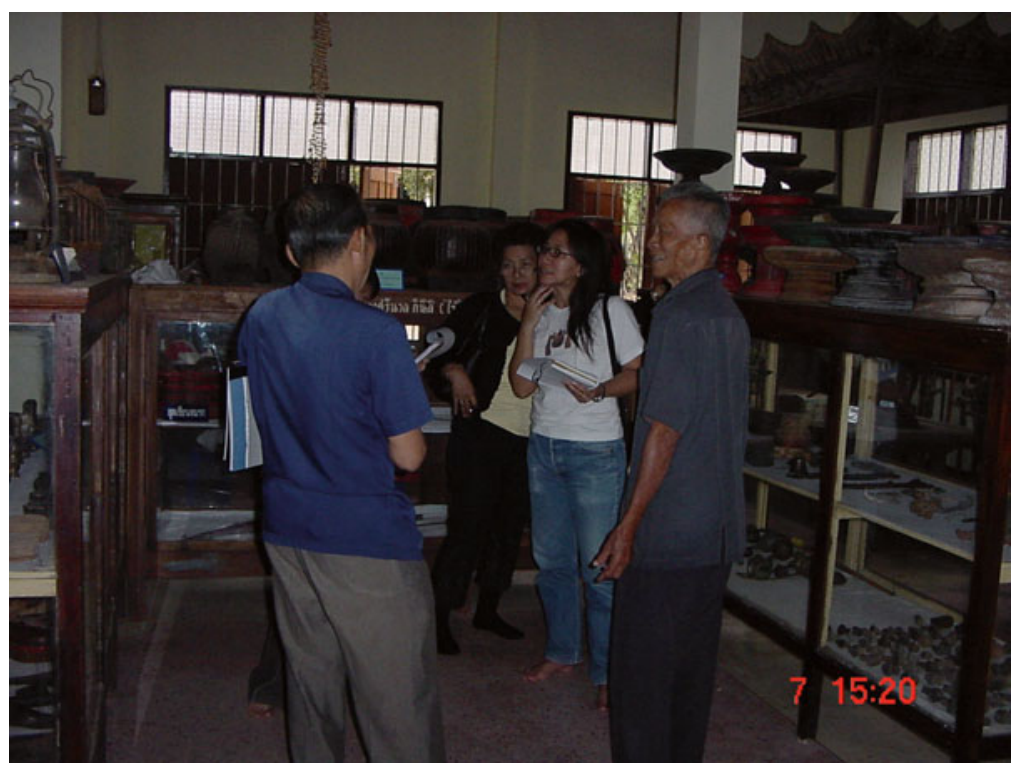

Fig. 2 Wat Laihin Museum, Lampang: a local museum located in a temple and managed by a community of Ban Laihin village

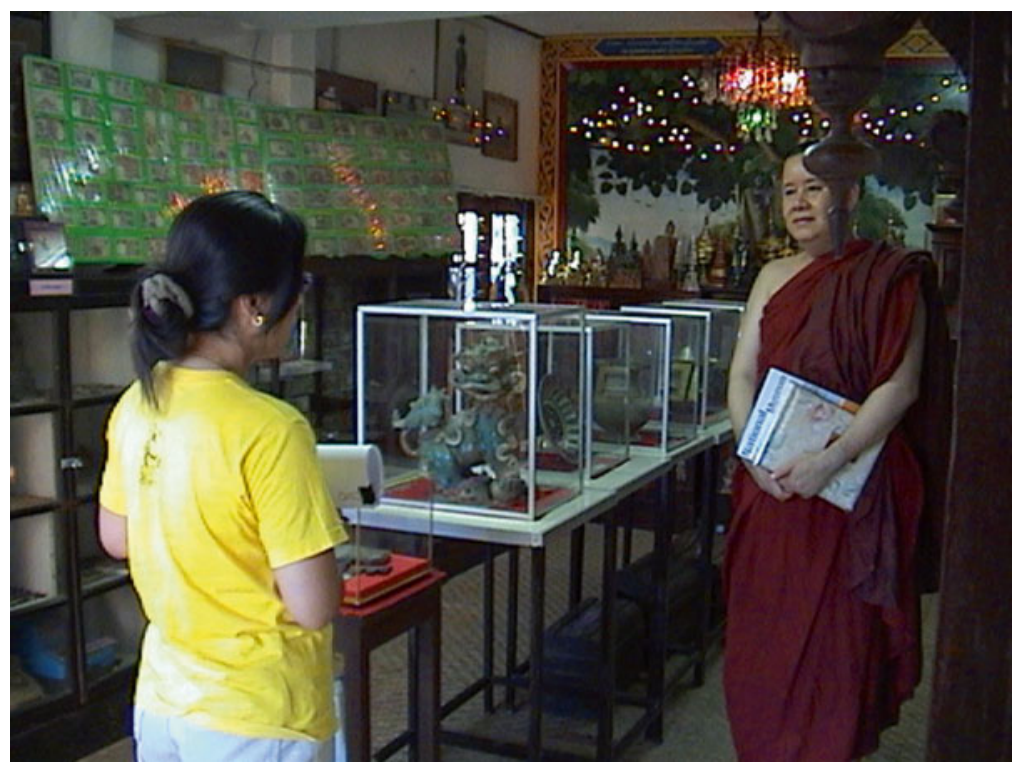

Fig. 3 Wat Pazang Museum, Lamphun: a local museum located in a temple and managed by an abbot of Pazang Temple 
The information from research papers about the situation in northern local museums by Chiang Mai Rajabht University (Jiraphong 1991) and Fine Arts Department (Fine Arts Department 1993) during 1991-1993 says that the number of local museums in the north is 170 . There are only six local museums that function as community museums. There were just a few community museums in the northern area 20 years ago. Now, the number of community museums has increased but some community museums in the last list have closed because of unstable policy and museum organization. In most local museums managed by temples or communities, the head was the abbot of the temple, director of the school, chief of the village, etc., so when the head changed, the policy also changed. If there was a new chief without interest in museum work, that museum always closed.

\section{Community Museums in the North of Thailand}

The community museums in the north have different patterns depending on collection, content, and organization. We can recognize patterns of community museums to be the following:

\subsection{Ethnicity Museum}

Most ethnicity museums are located in the community of those ethnic people. They have two objectives: the first is presentation of ethnic identity, history, and folklore as a place of memories, as a place for teaching their community, and as an ecotourist place. The second objective is a tool for promoting human rights or their cultural identity as one path of Thai society.

Thai museologists often say that this type of museum is a living exhibition because they model ethnic life such as traditional houses, barns, and folk life collections to exhibit as original houses that might already be changing in the real way of life. Visitor services are not formal services like in national museums or private museums. A visitor can visit by themselves during the day. But if they need a museum guide or an event for group tour visitors, they must make an appointment with the temple or community in advance.

Ethnicity museums organize interactive activities with community at least once a year. The most numerous type of activity is religious ritual fairs, using the museum as the center of the fair.

It is not only the outside form of the museum that is different; the management is also different in each museum.

As for Tai Khoan ${ }^{1}$ Museum at San Kang Pla Temple in Chiang Mai (Fig. 4), the current abbot of the temple built this museum in 1994 to present the cultural uniqueness of the Tai Khoan people, who are the community around the temple. Although the abbot is not a Tai Khoan person, he wants to support the community 

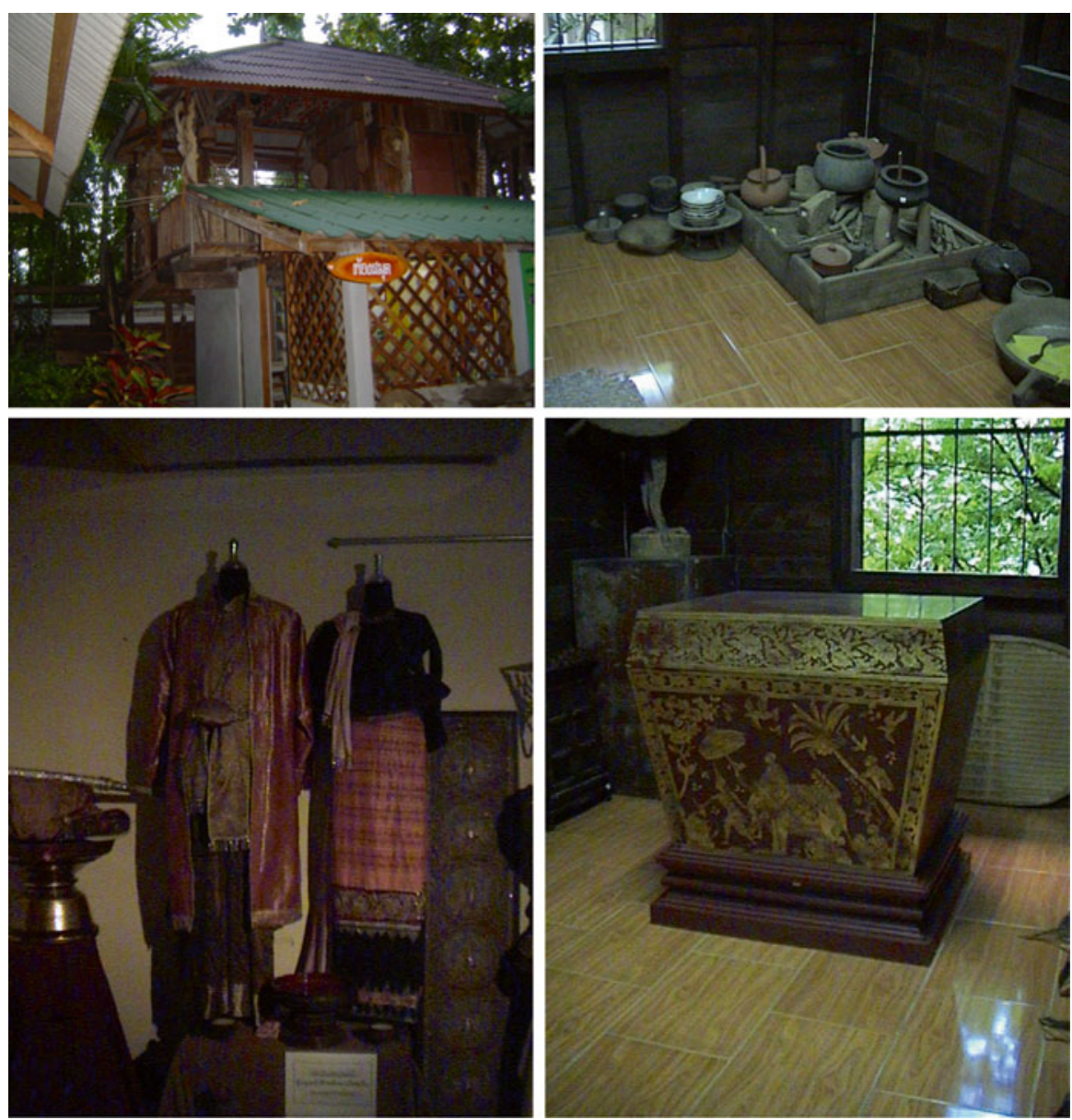

Fig. 4 Tai Khoan Museum at San Kang Pla Temple, Chiang Mai

around the temple to preserve their identity and present their social life. He interacts with the Tai Khoan community by calling for cooperation in building a traditional Tai Khoan house to be a museum in the temple area and donation of appliances to collect and display in the museum. Each year, the abbot will organize a Buddhist event so that visitors will visit this museum and see its merit. He said that the community of Tai Khoan will benefit from selling local products to visitors in this event.

Some notice from this museum management that the community does not really have a role in the museum because the abbot has all authority. And the community built an ethnicity museum in the village for their events after the museum was built at the temple. This is one case of a pale image of the community museum in Thailand.

The Tai Yong ${ }^{2}$ Museum at Pa Tal Temple in Chiang Mai (Fig. 5) is located in the temple and its purpose is to present the identity of ethnic people, the same as the Tai 

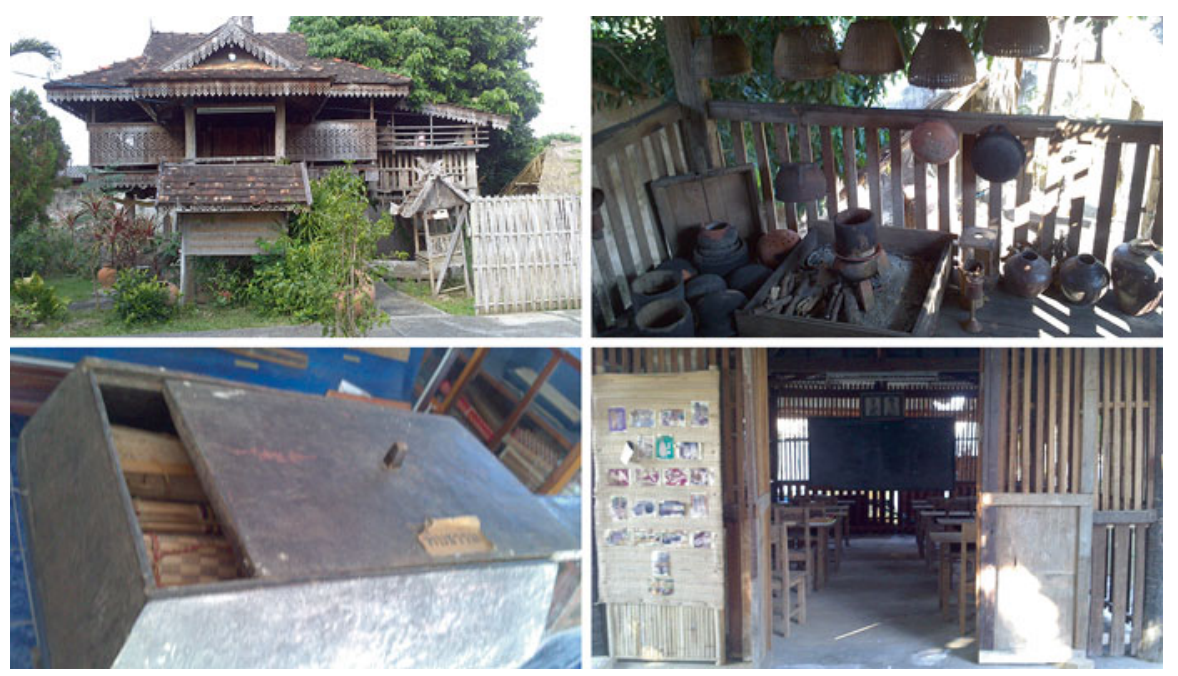

Fig. 5 Tai Yong Museum at Pa Tal Temple, Chiang Mai

Khoan Museum, but its management is different. The Tai Yong are an ethnic people who live around $\mathrm{Pa}$ Tal Temple. In 1999, they started to establish a museum in $\mathrm{Pa}$ Tal Temple, which is the center of the community, to present their unique culture and call for their ethnic people's rights to be admitted by society. They also use the museum as an ethnic cultural center for their youth.

The special point of this museum is establishment and management by the community. They share money to raise a budget of 300,000 baht for building the museum and donation appliances for the museum collection. The first museum gallery models a traditional house and displays its collection based on the original function of each room. The second gallery is an old barn from the village to model their folk agricultural methods. The last is a gallery of the Yong language, with a collection of palm leaf and mulberry manuscripts, and a small classroom for learning the Yong language of the community. Nowadays, the museum is used as a center for the community to organize activities to promote power of mind of the community to preserve their ethnic culture.

One ethnicity museum purpose is to be an eco-tourist site such as the Garden \& Museum of Mong ${ }^{3}$ Village in Doi Puy, Chiang Mai. It was established and is managed by 15 Mong families in the community. In 1987, they modeled three galleries to display a collection of Mong appliances with an explanation board. In the time after harvest, a group of Mong ladies come to do needlework and sell their products to tourists. During holidays, a student will guide the tourists at the museum to earn money, which cost is part of the community budget for museum maintenance.

This museum really seems to be a community museum because it is managed by the community and supports their economy. 


\subsection{Local Historical Museum}

This community museum is located in a historical area related to the folk life of the community. The main objective of the museum is to present the history of the area and the community. An important part of their collection is folk objects from this area and communication.

Wat Kaet Museum (Fig. 6) is a local historical museum in the Wat Kaet Karam business quarter on the bank of the Ping River in Chiang Mai. This museum started by collecting many votive objects in Wat Kaet to display as a collection in a gallery. These objects are appliances offered by the Wat Kaet community to Buddha, so they are important local historical evidence to relate the story of the families, the community, and all in this area.

The interesting point of this museum is management and cooperation by the community. The Committee for Preservation and Development of the Business Quarter has authority in the museum and organizes events.

The First Royal Factory Museum (Fang) in Chiang Mai (Fig. 7) is a museum where the current effects of royal projects in development of the ethnic communities in the area are displayed. The museum tries to interact with the community around the museum through the "Youth Guide": the youth who take a guide training and
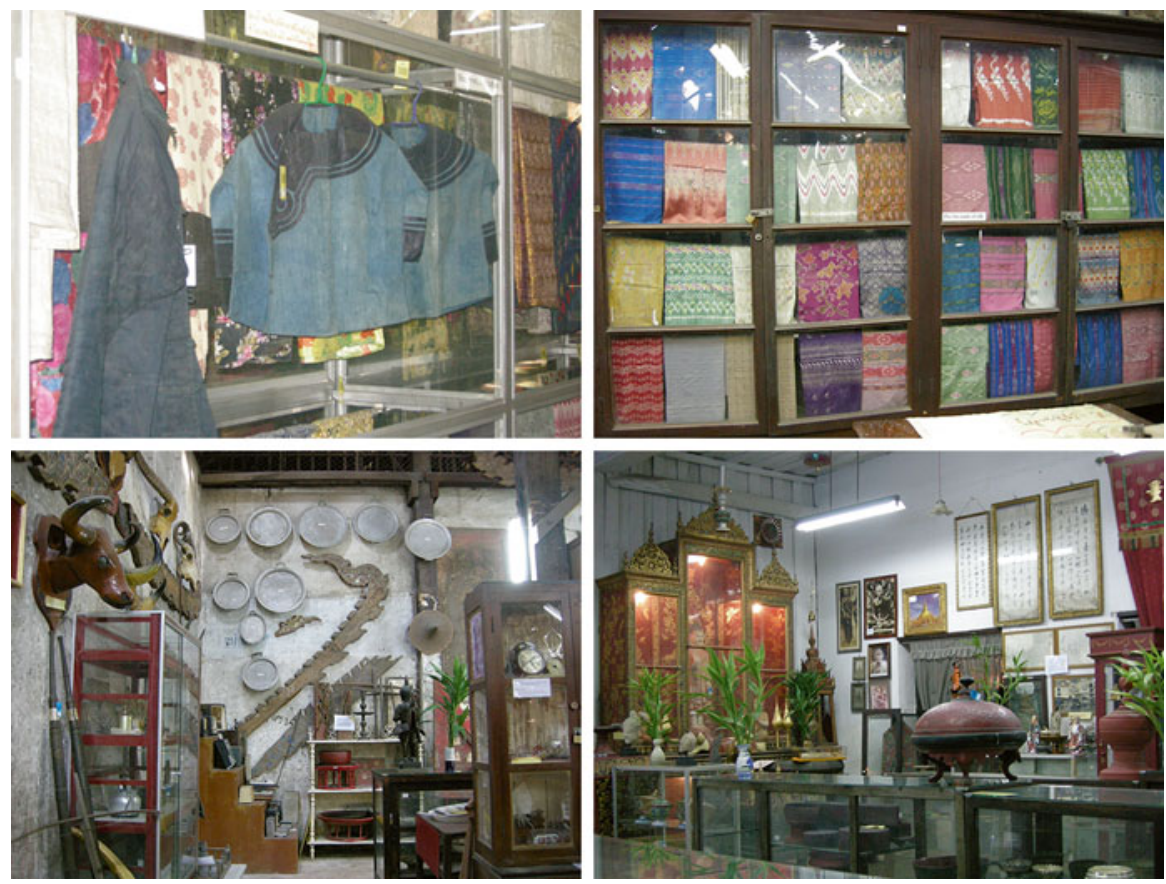

Fig. 6 Wat Kaet Museum: a local historical museum 

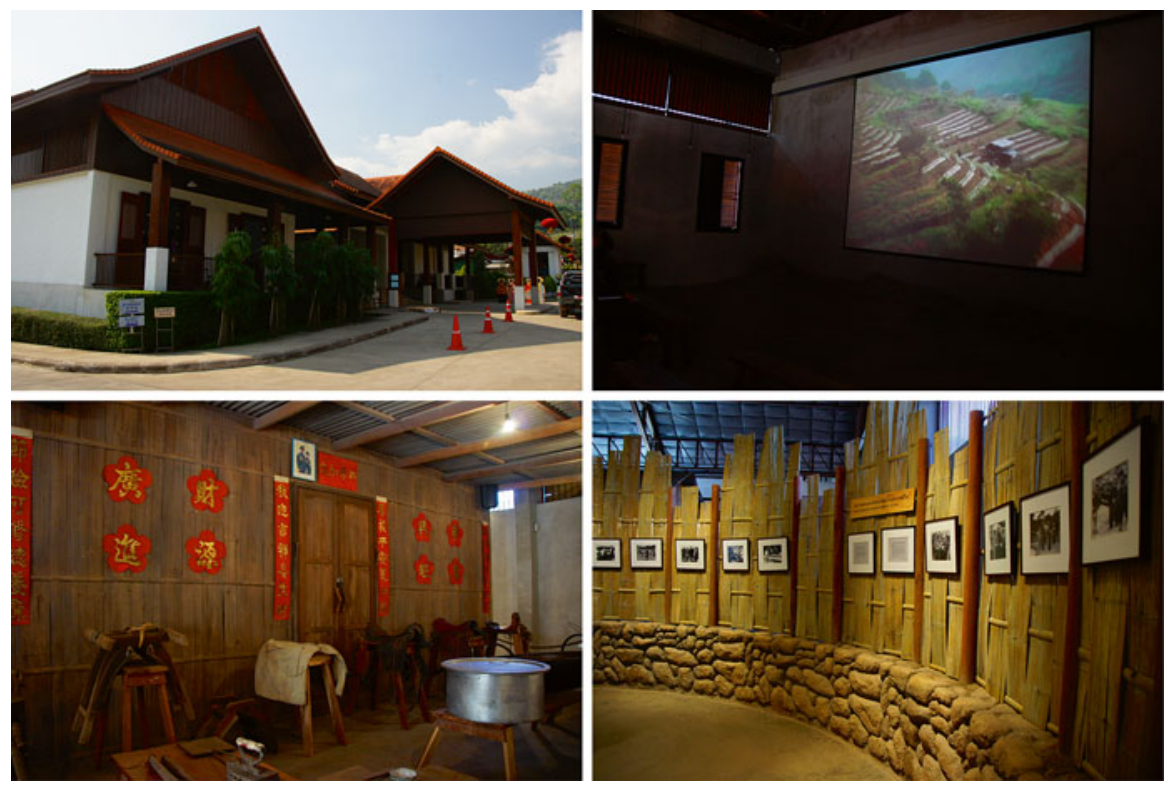

Fig. 7 The First Royal Factory Museum (Fang) in Chiang Mai

work at the museum in their holidays. The museum staff support them in guiding visitors through the village. The museum said, this is a way to link museum's content and benefit to the community around museum.

Community museums in Thailand might be just one type of local museum managed by people, temples, and private units that is a path of the local community. Their situations might not be as stable as those of the national museums because the idea of each community unit is different in its understanding of the museum's social function. And nowadays, most museums are just used as tourist places for the community economy.

\section{Notes}

1. The Tai Khaon is a group of ethnic people whose original settlement was in the north of Myanmar. The Tai Khaon people emigrated to populate northern Thailand in the Lan $\mathrm{Na}$ period, an old kingdom of northern Thai, thirteenth century (Kanokmongkol 2005).

2. The Tai Yong is a group of ethnic people whose original settlement was in the north of Myanmar. The Tai Yong people emigrated to populate northern Thailand in the Chiang Mai period, eighteenth century (Kanokmongkol 2005).

3. The Mong is a hill tribe who live on mountains in Thailand, Laos, Myanmar and South China (Kanokmongkol 2005).

Open Access This chapter is distributed under the terms of the Creative Commons AttributionNonCommercial 4.0 International License (http://creativecommons.org/licenses/by-nc/4.0/), which permits any noncommercial use, duplication, adaptation, distribution and reproduction in any medium or format, as long as you give appropriate credit to the original author(s) and the source, provide a link to the Creative Commons license and indicate if changes were made. 
The images or other third party material in this chapter are included in the work's Creative Commons license, unless indicated otherwise in the credit line; if such material is not included in the work's Creative Commons license and the respective action is not permitted by statutory regulation, users will need to obtain permission from the license holder to duplicate, adapt or reproduce the material.

\section{References}

Jiraphong, Buppa. 1991. The situation of local museum in Chiang Mai. Chiang Mai: Chiang Mai Rajabhat University. (In Thai).

Kanokmongkol, Nitaya (ed.). 2005. Research paper of ethnicity knowledge in Thailand for establishment the Ethnological Museum of Thailand. Pathum Thani Province, Thailand: Kanjanaphisek National Museum, Fine Arts Department (In Thai).

Sirindhon Anthropology Center. 2008. Museum memo: Realize experience from museum research and development. Bangkok: Samlada Company. (In Thai).

Fine Arts Department. 1993. Directory of museum in the north of Thailand. Bangkok: Amrin Printing \& Publishing. (In Thai). 